\title{
An integrated model for determining business intelligence systems adoption and post-adoption benefits in banking sector
}

\author{
Owusu Acheampong ${ }^{1,}$ *, Said Aiman Moyaid ${ }^{2}$ \\ 1,2 Limkokwing University of Creative Technology Cyberjaya, Malaysia
}

\section{Keywords:}

Business intelligence systems

Adoption

Diffusion of innovations

Technology-organization-

Environment framework

Balanced scorecard

Received: 28 February 2016

Accepted: 3 March 2016

Published: 26 April 2016

\begin{abstract}
Business Intelligence (BI) Systems have been theorized as providing immerse benefits to organizations that adopt them. These benefits include: improved customer satisfaction improved decision-making process, provision of faster and more accurate reporting, increased revenues and increased competitive advantage. However, there are limited studies on the factors affecting adoption and actual benefits accruing to organizations adopting the system. The main aim of this study is to develop an integrated model for determining BI System's adoption and post-adoption benefits in banking industry. The proposed model is an integration of the Diffusion of Innovations Theory (DOI), Technology-Organization-Environment (TOE) Framework, the Institutional Theory (INT), and Kaplan \& Norton's Balance Scorecard (BSC). This model is different from other studies in the context of organizational adoption of BI Systems as it integrates the determinants, and evaluation of the benefits of the technology in one study. There is also a moderator Time since adoption which is used to moderate the impact of the extent of adoption to organizational performance.
\end{abstract}

(C) 2016 The Author(s). Published by TAF Publishing.

\section{INTRODUCTION}

In this age of globalization, emerging markets, rapid change and increasing regulations, organizations look for best practices and software tools that can aid management in business decision making (Rob \& Coronel, 2009). Therefore, one key technology that had received a lot of attention from academia and practitioners recently is Business Intelligence (BI) Systems (Olszak \& Ziemba, 2012). BI Systems can leverage a company's IT Systems and other technologies such as Enterprise Resource plann-

*Corresponding author: Owusu Acheampong

E-mail: owuach@hotmail.com ing (ERP) and data warehouse together by providing good reporting and analysis which can support management in decision making (Ritacco \& Carver, 2007).

In addition, extant literature has reported about the enormous benefits of BI Systems to organizations that have implemented them such as: providing faster and more accurate reporting, increased revenues, savings in information technology (IT) resources required, an improved decision-making process, improved customer satisfaction and improved communication within the organization(Thompson, 2004; Hočevar \& Jaklič, 2008; Ritacco \& Carver, 2007; Blumberg \& Atre, 2003; Mancini \& Vaassen, Dameri, 2013; Zaman, 2005; Turban, Sharda, Aronson \& King, 2008). It has also been reported that 
these benefits are giving these organizations competitive advantage over their competitors (Matei \& Bank, 2010; Rob \& Coronel, 2009; Negash, 2004; Davenport, 2006; Hočevar \& Jaklič, 2008). Again, BI Systems provide access readilyto the required information, which is easily absorbed by business users, leading to enhanced business decisions and eventually improving business performance (De Voe \& Neal, 2005; Lönnqvist \& Pirttimäki, 2006).

As a result, a lot of organizations have implemented BI Systems using Critical Success Factors (CSFs) and Maturity Models (MMs) (Dawson \& Van Belle, 2013; Fedouaki \& El Alami, 2013; Mungree, Rudra \& Morien, 2013; Olbrich, Pöppelbuß \& Niehaves, 2012; Olszak \& Ziemba, 2012; Ong \& Siew, 2013; Hribar Rajterič, 2010; Yeoh, Koronios, \& Gao, 2008; Yeoh \& Koronios, 2010). Currently, many organizations are using BI tools (for example,online analytical processing (OLAP), Data warehouse, Dashboards, Data Mining, Reporting, and so on) (Zaman, 2005) to deal with both structured and semi-structured data (Blumberg \& Atre, 2003; Rudin \& Cressy, 2003) to present value-added and meaningful reports which can then aid management in decision making. A lot of these systems are found in the banking sector due to the large volumes of data from heterogeneous data sources of financial business they have to manage in their operations (Kannan, Pappathi, \& Karnan, 2012). Lin \& Lin (2008) reported that, in a modern bank network, several customer data accountsand transactions are generated daily, and with the increased speed of business changes and higher competition, the need for bank intelligence has grown dramatically. According to (Turban et al., 2008; Zaman, 2005) BI is "an umbrella term which encompasses architectures, tools, databases, analytical tools, applications and methodologies that aid in management decision making". They further explained that BI like its predecessor, Decision Support Systems (DSS), means different things to different people, asit is a context-free expression. As such, various authors have given different definitions to BI. For example (Rob \& Coronel, 2009) defined BI as "a term used to describe a comprehensive, cohesive, and integrated set of tools and processes used to capture, collect, integrate, store, and analyze data with the purpose of generating and presenting information used to support business decision making". However, in this study, BI is defined as "a broad category of applications, technologies, and processes for gathering, storing, accessing, and analyzing data into actionable information to help business users make better decisions in order to improve business performance (Watson, 2009; Azvine,
Cui \& Nauck, 2005:215). However, despite all the advantages and benefits of BI Systems, the BI Systems planning and implementation demand a large amount of resources and numerous enterprise stakeholders for some number of years (Blumberg \& Atre, 2003; Olszak \& Ziemba, 2007; Reinschmidt \& Francoise, 2000). This has led to the development of many BI Maturity Models (MMs) (Chuah \& Wong, 2011; Hribar Rajterič, 2010) to assess and also aid in BI implementation in organizations. Also, because most of the benefits of BI are intangible, many managers do not insist on its cost justification (Eckerson, 2003; Turban et al., 2008:22). As a result, it is advisable for organizations to evaluate the impact of their BI Systems implementation from time to time to determine whether indeed the cost of embarking such a project is justified so that these huge investments are not wasted.

In spite of all these, currently, many studies on BI have focused on its applications developmentas shown in the study by (Aruldoss, Lakshmi \& Prasanna Venkatesan, 2014) about "A survey on recent research in business intelligence". Côrte-Real, Ruivo \& Oliveira (2014) emphasized this in their research about "The diffusion stages of business intelligence \& analytics (BI\&A): A systematic mapping study", where they surveyed a total of 30 articles from 11 journals and 8 conferences through a review of the literature. Their findings revealed that "little attention has been given to BI\&A post-adoption stages and propose future research line on this area". Furthermore, they called for a theoretical-based deeper insights which will help researchers get better understanding for the main motivational factors and barriers that will enable users to adopt or hinder them from BI\&A. In addition, extant literature shows that there are few empirical studies when it comes to organizational adoption of BI Systems based on adoption theories (DOI, TOE, INT) as many have been done at the individual level (Grublješič \& Jaklič, 2015; Hou, 2014; Hou, 2012; Kester \& Preko, 2015; Pilz \& Ferraz, 2013; Yoon, Ghosh, \& Bong-Keun Jeong, 2014). Also, most of the existing studies have focused mainly on Maturity Models (MMs) for measuring the current state of BI Systems as well as Critical Success Factors (CSFs) for BI Systems implementation in large organizations and Small Medium Enterprises (SMEs) in different parts of the world especially advanced economies(Dawson \& Van Belle, 2013; Fedouaki \& El Alami, 2013; Hawking, Jovanovic, \& Sellitto, 2011; Hawking, 2013; Khojasteh, 2013; Mungree et al., 2013; Olbrich et al., 2012; Olszak \& Ziemba, 2012; Olszak, 2013; Ong \& Siew, 2013; Hribar Rajterič, 2010; Yeoh et al., 2008; 
Yeoh \& Koronios, 2010). Again, there are very few studies that have looked at the post-adoption effects of BI Systems on organizational performance (Elbashir, Collier, \& Davern, 2008; Hou, 2015). Yet again, most of the studies have been done in the developed world leaving developing countries especially sub-Saharan African countries behind although there are few studies from South Africa and Ghana which are exploratory, triangulation and adoption at individual levels (Bijker \& Hart, 2013; Hartley \& Seymour, 2011; Kester \& Preko, 2015; O'Brien \& Kok, 2006; Ponelis \& Britz, 2011). This is a research gap that needs to be filled. As a result, future study based on theIntegrated Model developed from this current study, will use the Banking sector in Ghana as the target population for data collection and analysis, to help fill the literature gap, by empirically determining the influencing factors to BI Systems adoption and the post-adoption effects on Business Performance in the banks. Some key questions that come to mind are:

1. What is the extent of BI Systems adoption in the Banks?

2. What are the factors that influence the Banks to adopt BI Systems?

3. Are the Banks really enjoying the benefits that have been reported about BI Systems in the literature?

4. Does foreign influence play a significant role in terms of the extent of BI Systems adoption in Foreign Banks compared to the Local Banks?

5. Similarly, is the level of BI Systems adoption of Local Public Banks higher than that of Local Private Banks?

Thus, the main purpose of this study is to develop an integrated organizational adoption model that can be used to determine the key factors influencing BI Systems adoption in banks and also measure the post-adoption effects on the bank's business performance.

The rest of the paper is organized in the following manner. In the next section, the authors discusses the review of related studies which comprises of BI Systems applications, organizational adoption of innovations together with the underpinning theories for the study. The next section provides the methodology which includes how the integrated model was developed, together with the integrated model and the constructs, and hypotheses for the study. The last section is the conclusion of the study with contributions and suggestions for future studies.

\section{LITERATURE REVIEW}

For this study, the review of the literature was done on relevant extant academic studies covering applications of BI Systems especially in the banking industry. Also, related studies on BI Systems adoption and other innovations adoption were considered based on the Diffusion of Innovations Theory (DOI)(Rogers, 1995), the TechnologyOrganization-Environment (TOE) Framework (Tornatzky \& Fleisher, 1990), the Institutional Theory (INT) (Scott, 1995; DiMaggio \& Powell, 1983; Meyer \& Rowan, 1977), and Kaplan \& Norton's Balance Scorecard (BSC) (Kaplan \& Norton, 1992)where the Integrated Model was developed.

\section{BI Applications in the Banking Industry}

According to Turban et al., (2008) and Eckerson (2003), BI systems are designed with the main objective of enabling interactive data access, data manipulation, and giving analysts and business managers the ability to conduct appropriate analysis. This is usually summed up as providing the "single version of the truth" across an entire organization. They further elaborated that the analyses of current and historical data, situations and performances, give valuable insights to decision makers which enable them to make more informed and better decisions (Turban et al., 2008; Zaman, 2005). Thompson (2004) explained that most common BI applications areas are: sales and marketing analyses, financial consolidation, planning and forecasting, statutory reporting, budgeting and profitability analysis, and general reporting, which are needed for the survival of businesses. Specifically in the Banking sector, Ubiparipovi (2011) listed and explained some of the most common applications BI Systems bring to the banking industry. These include Customer Relationship Management (CRM-which handles issues such as customer interaction analysis, customer investment profile, customer complaints and so on); Performance Management (PM-this handles issues such as transaction analysis, profitability analysis, customer profitability, and so on); Risk Management (RM-deals with issues such as interest rate risk analysis, outstanding analysis, collection analysis and so on); Asset and Liability Management (ALM-deals with issues such as interest rate sensitivity, liquidity analysis, income analysis and so on); and Compliance (handles issues such as financial capital adequacy analysis, structure of regulatory capital, suspicious activity analysis, and so on). He continued further to explain that Data warehouse and OLAP form the informational basis for the application of BI in the banks. Also, Data mining and knowledge retrieval are important segments of BI and deal with complex statistical analysis, discovering "hidden" relationships between data and forecasting the behavioral trends of business systems (Ubiparipovi, 2011). Curko \& Bach (2007) also explained 
the applications of BI and business process management (BPM) in banking operations. They listed some of the most widely used BI applications in banking as: Risk management (used for avoiding a loan default and detection and prediction of fraud); Selling of additional products to existing customers (used for exploiting up-sell and cross-sell opportunities); Reducing Churn rate (using BI techniques such as data mining to assess a probability that a client will cease transactions or churn after the discounted period); Segmenting(used for categorizing customers in order to segment profitable customers); Client Lifetime Value (used for estimating expected revenue from customers in the future period); Activation (enables activation models to be build which are used for estimating probability that a new customer will really use a newly stipulated service or product and become profitable) and Business Process Management (BPM-used for raising efficiency which is usually demanded by regulators).

\section{Previous Studies on Organizational Adoption of Innovations}

As this study pertains to organizational adoption of BI Systems, the study formulated the Integrated Model drawing from the DOI, TOE and INT, as the underpinning theories for determining the factors influencing BI Systems adoption and the extent of adoption. The BSC was also used to measure the post-adoption effects of BI Systems on organizational performance. This was done as a lot of researchers have proposed methodologies that combine at least two or more theories because that gives better understanding of the adoption of new technologies (Oliveira \& Martins, 2011). Also, many studies focusing on technology innovation adoption at the organizational level use these theories (Chong, Lin, Ooi \& Raman, 2009). Oliveira et al. (2014) further explained that Diffusion of Innovations and Technology-Organization-Environment framework have been used widely in various innovation adoption studies, and they have enjoyed regular empirical support. They continued further to say that, the TOE perspectives interrelate with the innovation features identified by Rogersin so many ways. This has resulted in the combination of the TOE contexts to strengthen the DOI theory being highly-accepted (Chau \& Tam, 1997; Oliveira \& Martins, 2011). Also, the INT theory supplements the environmental dimension of the TOE framework's external pressures, which include pressure from competitors as well as pressure exerted by clients and trading partners (Oliveira \& Martins, 2011). Determining the business value of BI Systems is often not done as there is lack of measurement methods and resources. Hou (2015) confirmed the lack of empirical research especially on measuring the value of BI Systems although the BSC has been applied in various innovation contexts and thus applied the BSC to empirically assess the effect of BI System usage on organizational performance. As a result, this study is justified in combining these theories. Theories pertaining to individual adoption of technologies such as Theory of Planned Behavior (TPB), Unified Theory of Acceptance and Use of Technology (UTAT), Technology Acceptance Model (TAM), and Theory of Reasoned Action (TRA), were not considered as they pertain to individual's adoption of technology.

\section{Diffusion of Innovations Theory}

According to Rogers (1995) Diffusion of Innovation (DOI) theory, the rate of adoption of innovations is influenced by five factors: compatibility, relative advantage, observability, complexity, and trialability. He continued further to explain that whilst complexity is mostly negatively related with the rate of adoption, trialability, relative advantage, observability, and compatibility are usually positively related with the rate of adoption (Rogers, 1995). However, researchers have found out consistently that technical compatibility, technical complexity, and relative advantage are main antecedents to innovations adoption (Bradford \& Florin, 2003; Crum, Premkumar \& Ramamurthy, 1996). A lot of studies have used this theory to predict innovation adoption behavior at both organizational and individual levels (Bharati \& Chaudhury, 2006; Bradford \& Florin, 2003; Peansupap \& Walker, 2005; Yoon et al., 2014; Zhu \& Kraemer, 2005).

\section{Technology-Organization-Environment Framework}

According to Tornatzky\& Fleisher (1990), TechnologyOrganisation-Environment (TOE) Framework, the process through which a firm adopts and implements technological innovations is influenced by three elements namely the technological context, the organizational context, and the environmental context. The three elements can both be opportunities and constraints for technological innovation adoption (Tornatzky \& Fleisher, 1990:154). They continued further to explain that the technological contextcomprisesof the internal and external technologies which are important to the firm and technologies may include both processes and equipment. The organisational context refers to the firm's characteristics and resources, which include the firm's size, degree of formalization, 
degree of centralization, managerial structure, and amount of slack resources, human resources, and linkages among employees. The environmental context comprises of the structure and size of the industry, the macroeconomic context, the firm's competitors, as well as the regulatory environment (Tornatzky \& Fleisher, 1990). TOE has been used to investigate the adoption of technological innovation in many areas(Lai, Lin, \& Tseng, 2014; Malladi, 2013; Oliveira \& Martins, 2010a, 2010b; Pan \& Jang, 2008; Puklavec \& Oliveira, 2014). Others have also combined the TOE with DOI (Côrte-Real et al., 2014; Sujitparapitaya et al., 2012; Hung, Hung, Tsai \& Jiang, 2010; Ifinedo, 2011; Ramamurthy, Sen \& Sinha, 2008; Thiesse, Staake, Schmitt, \& Fleisch, 2011).

\section{The Institutional Theory}

Weerakkody Dwivedi \& Irani (2009) explained that organizations work in environments which are usually dependent by the economic, socio-political, and technological influences, and that the Institutional theory (INT) has been used by many researchers to study the impact of these external forces on organizational behavior. Yet few studies have focused on using this theory to understand the diffusion and adoption of innovations and the impact of change in organizationsdue to IT/IS influences (Weerakkody et al., 2009). Weerakkody et al., (2009) and Scott (1995) further explained that the institutional environments are described by the elaboration of requirements and rules to which the individual organizations need to adapt if they are to receive legitimacy and acceptance. As a result, for organizations to endure, they need to conform to the belief systems and rules prevailing in the environment in which they exist (Scott, 1995; DiMaggio \& Powell, 1983; Meyer \& Rowan, 1977; Weerakkody et al., 2009). DiMaggio \& Powell (1983) argued that this drive for legitimacy leads to the processes of institutionalization which in the long run, makes organizations more similar but not necessarily making them more efficient, and thus giving rise to institutional isomorphism. Again (DiMaggio \& Powell, 1993) postulated that there are three different types of institutional isomorphism that can influence firms to adopt innovations. These are the mimetic, coercive and normative. They continued further to explain that mimetic isomorphism are powerful forces that encourage firms to imitate others in the same industry. Coercive isomorphism comes from both the formal and informal pressures exerted in the firms by other firms which they depend on and by the cultural expectations of the society within which they operate which could include government regulations and policies. Normative isomorphism arises as a result of professionalization which is defined as "the collective struggle of members of an occupation to define the conditions and methods of their work, to control the production of the future member professionals, and to establish a cognitive base and legitimization for their occupational autonomy" (DiMaggio \& Powell, 1983:152). Therefore, firms in the same industry tend to become homologous over time as customer, competitive, and other stakeholders' pressures influence them to copy other leaders in the same industry (Oliveira \& Martins, 2011). Some recent studies have used INT for innovation adoption (Baptista, 2009; Bharadwaj \& Lal, 2012; Hedman \& Borell, 2004). Other studies have also combined the TOE framework with the INT (Soares-Aguiar \& Palma-dos-Reis, 2008; Gibbs \& Kraemer, 2004) and the DOI with INT (Bharati \& Chaudhury, 2006).

\section{Kaplan \& Norton's Balance Scorecard}

The Balance Scorecard (BSC) is a method used to measure organizational performance in four different perspectives, namely Learning \& Growth, Internal Business Process, Customer, and Finance, which is usually derived from the organization's vision and strategy. Originally developed by (Kaplan \& Norton, 1992), they argued that financial metrics alone such as return on investments (ROI) and earnings per share cannot be used to measure the entire effects of technology on organizational performance, and that other non-financial indicators can also have an effect, hence a balanced measurement method. A review of the literature shows that apart from general organizational performance, the BSC is also frequently used to measure the effects of the introduction of a new IS or IT on organization's performance (Park \& Rim, 2011). The Customer perspective seeks to answer the question: "To achieve our vision, how should we appeal to our customers?"(Kaplan \& Norton, 1996). This is usually measured by "lead times, quality, performance \& service, and costs"(Kaplan \& Norton, 1992). Internal Business processseeks to answer the question: "To satisfy ourshareholders and customers, what business processes must we excel at?"(Kaplan \& Norton, 1996). This is usually measured by“cycle time, quality, employee skills, and productivity, to track them"(Kaplan \& Norton, 1992). Innovation and learningperspective seeks to answer the question: "To achieve our vision, how will we sustain our ability to change and improve?"(Kaplan \& Norton, 1996).This is usually measured by "monitoring the 
company's ability to launch new products, create more value for customers, and improve operating efficiencies" (Kaplan \& Norton, 1992). Financial perspective seeks to answer the question: "To achieve our vision, how should we appear to our customers?" (Kaplan \& Norton, 1996). This is usually measured by "cash flow, quarterly sales growth, operating income by division, and increased market share by segment and return on equity" (Kaplan \& Norton, 1992). Kaplan \& Norton (2004) further explained that the financial perspective is a lag indicator which is dependent on the success of the other perspectives and provides the main definition of an organization's success. They continued further that customers' success provides the key component for improved financial performance. In addition, the performance of the internal process gives the lead indicator of subsequent boosts in customer and the financial outcomes. Again, learning and growth improvements which are intangible assets, are the ultimate source of sustainable value creation and serve as the lead indicators for internal process, customer and financial performance perspectives (Kaplan \& Norton, 2004).

Extant literature shows that since the introduction of the BSC, a lot of studies from widely-varying research areas have used it to measure organizational performance (Chand, Hachey, Hunton, Owhoso, \& Vasudevan, 2005; Fang \& Lin, 2006; Hou, 2015; Kim, Suh \& Hwang, 2003; Lee, Chen \& Chang, 2008; S. Lee, Park, \& Lim, 2013; Lin, Hsu \& Ting, 2006; Michalska, 2005; Park \& Rim, 2011; Wu \& Chen, 2014). More specifically on BI Systems and its related technologies, (Hou, 2015) used the balanced scorecard to assess the impact of BI system usage on organizational performance using data from Taiwan's semiconductor industry. Rahman (2013) used the balanced scorecard to develop a framework for measuring the performance of Data Warehouses.

\section{Related studies on BI Systems Adoption}

Empirical studies of BI Systems adoption at the organizational level based on innovation adoption theories (DOI, TOE, INT) are still limited and of varying methodologies as explained earlier on. For example, the following authors used qualitative case studies to explore BI Systems adoption: pervasiveness of organizational BI in South African firms (Bijker \& Hart, 2013) BI adoption in retail chain in Slovakia (Olexová 2014) BI Systems adoption determinants in different companies located in the European Union (Puklavec \& Oliveira, 2014). Also, other authors have developed conceptual frameworks that can be used to determine BI Systems adoption with no empirical evidence. For example, user acceptance of BI (Yoon et al., 2014), and adoption of BI by SMEs (Boonsiritomachai \& Mcgrath, 2014). However, the following authors performed empirical quantitative survey-based studies to determine BI Systems adoption: determinants of the adoption and application of BI in Australian companies (Chaveesuk, 2010); BI adoption in academic administration in USA institutions of higher educations (IHEs) (Sujitparapitaya et al., 2012), and adoption of BI\&A in North American organizations (Malladi, 2013). Thus this integrated model will help contribute to the existing adoption studies at the organizational level for BI Systems based on the organizational innovation adoption theories.

\section{METHODOLOGY}

\section{Integrated Model Development}

The research model of this study has been developed from review of extant academic literature, more especially empirical studies based on the underpinning theories used for the study. The Integrated Model is divided into the Independent Variables (IVs), the Mediating Variable, Moderating Variable, and finally the Dependent Variable (DV).

\section{Independent Variables (IVs)}

For this study, the IVs are categorized into three distinct dimensions based on the three elements from the TOE framework. These are the Technological factors, Organizational factors and the Environmental factors. Various researches have proven that Technological factors alone cannot be the basis for innovation adoption and that other factors such as Organizational and Environmental also play a key role (Boonsiritomachai \& Mcgrath, 2014) and hence consider this approach for the research model. The Technological dimension constructs comprise of the DOI three main constructs: Relative Advantage, Complexity and Compatibility which have been constantly considered as the most important technological factors in the adoption process (Bradford \& Florin, 2003; Ifinedo, 2011). Based on the TOE framework and from extant literature of IS/IT innovations adoption, various constructs have been used to test for innovations adoption at the organizational level. On the basis of these, Organizational Size, Top Management Support, Presence of a Champion and Organizational Readiness have been chosen for the Organizational dimension constructs of this study (Gu, Cao \& Duan, 2012; Ifinedo, 2011; Lee \& Shim, 2007; Oliveira et 
al., 2014; Pearson \& Grandon, 2005; Premkumar \& Roberts, 1999; Ramamurthy et al., 2008; Thiesse et al., 2011; Y. Zhu, Li, Wang, \& Chen, 2010).

Combining the TOE framework and the INT and also based on extant IS/IT innovations adoption, Competitive Pressure and Regulatory Body have been chosen for the Environmental dimension constructs (Ifinedo, 2011; Lin \& Lin, 2008; Olbrich et al., 2012; Oliveira et al., 2014; Pearson \& Grandon, 2005).

\section{Mediating and Moderating Variables}

The Mediating Variable for this study is BI Systems Adoption (Ifinedo, 2011; Oliveira et al., 2014; Thiesse et al.,
2011) which acts as the DV for the determinants of the BI Systems adoption, but as an IV for the main DV (Organizational Performance) in this model. The Moderating Variable for this study is Time since Adoption (Bradford \& Florin, 2003; Hou, 2012).

\section{Dependent Variable (DV)}

The DV for this study is Organizational Performance (Park \& Rim 2011; Fang \& Lin 2006; Elbashir et al., 2008; Brynjolfsson \& Hitt 1995, 1996; Davenport, 2000; Varun Grover, 2001; Stratopoulos \& Dehming 2000; Bradford \& Roberts, 2001).

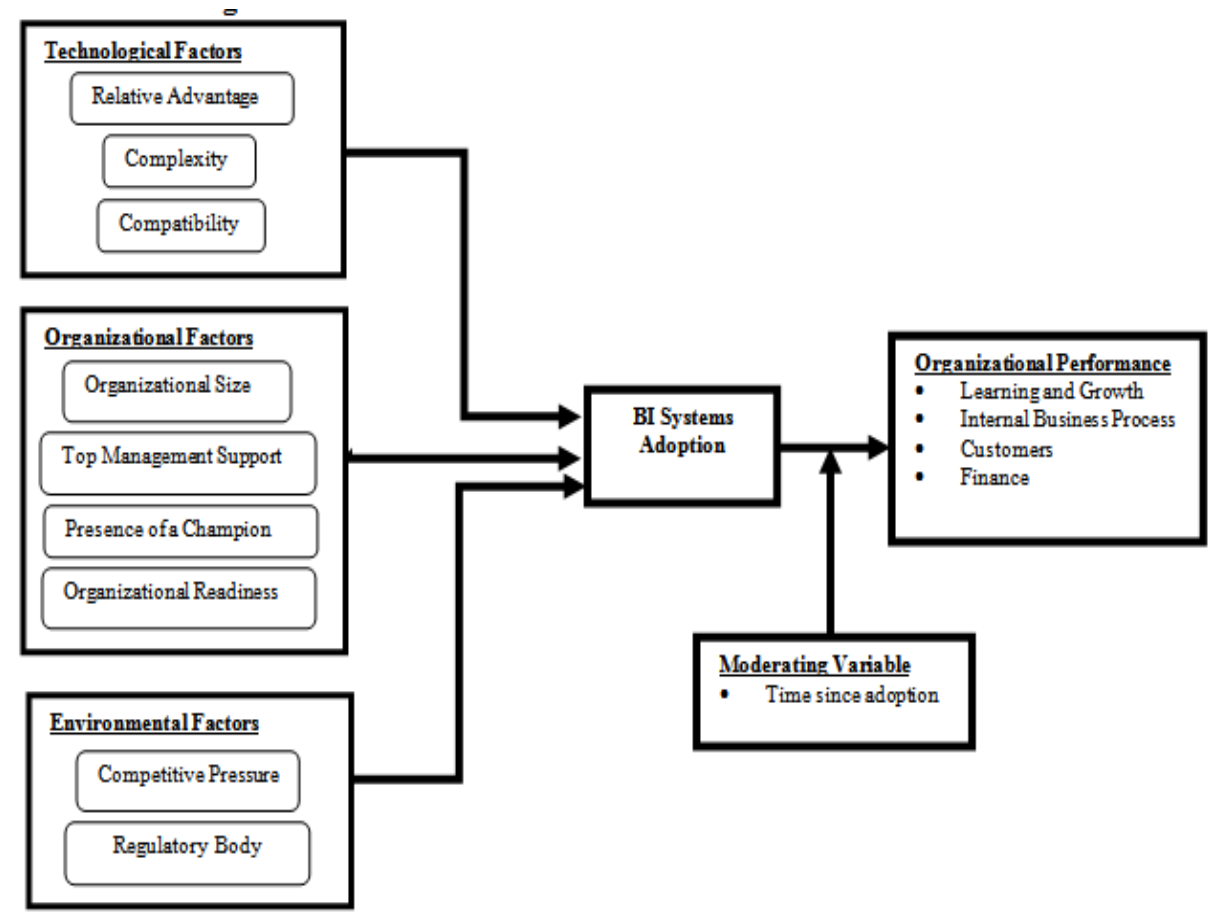

FIGURE 1. Integrated Research Model

\section{Constructs, their definitions and supporting literature with the Hypotheses}

With reference to Figure 1 above, the various Constructs together with the hypotheses for the study are discussed below.

\section{Technological Factors}

\section{Relative Advantage}

This refers to "the degree to which an innovation is perceived to be better than the idea it supersedes or existing systems" (Rogers, 1995). He continued further to explain that relative advantage is generally articulated in terms of social prestige, economic profitability, and other benefits such as cost

reduction, savings in time, and improvement in decision making which normally depend on the nature of the innovation. It is noted that the higher the perceived benefits of an innovation, the more likely its rapid rate of adoption (Ifinedo, 2011). A lot of studies have reported about the perceived benefits of BI Systems to organizations which makes it a potential innovation highly favored to be adopted by organizations (Gibson, Arnott, Jagielska \& Melbourne, 2004; Hočevar \& Jaklič, 2010; Ritacco \& Carver, 2007). Many studies have found that relative advantage perceived benefits were significant, positively related or the best predictor/determinant 
of the adoption of BI Systems and its close associates in different industries (Grublješič Coelho, \& Jaklič, 2014; Malladi, 2013; Olexová, 2014; Puklavec \& Oliveira, 2014; Ramamurthy et al., 2008; Ramamurthy, Sen, \& Sinha, 2008). However, other studies have also found that relative advantage does not play a significant role in some innovations adoption (Chaveesuk, 2010; Lai et al., 2014; Thiesse et al., 2011; Sujitparapitaya et al., 2012). Based on these, we therefore hypothesized that:

H1: The Relative Advantage of BI applications is positively related to BI Systems Adoption

\section{Complexity}

This refers to "the degree to which an innovation is perceived as difficult to understand and use" (Rogers, 1995). He continued further to explain that whilst some innovations are very clear in meaning to potential adopters, others are not. Therefore, new ideas that are easier to learn are adopted more rapidly than those that require the adopters to develop new skills for understanding (Ifinedo, 2011). Some studies have confirmed about the complex nature of BI Systems which can be a barrier to theiradoption (Yeoh et al., 2008). Various studies have found that complexity is insignificant and a barrier to various innovation adoption (Gu et al., 2012; Hung et al., 2010; Ifinedo, 2011; Lai et al., 2014; Premkumar \& Roberts, 1999; Thiesse et al., 2011). However, other studies have found complexity to be a key determinant in innovations adoption(Chaveesuk, 2010; Côrte-Real et al., 2014; Grublješič \& Jaklič, 2015; Lai et al., 2014; Olexová, 2014; Ramamurthy et al., 2008; K. Ramamurthy et al., 2008; Thiesse et al., 2011; Sujitparapitaya et al. 2012; Thong 1999). Based on these, we therefore hypothesized that:

H2 Complexity of BI applications is negatively related to BI Systems Adoption

\section{Compatibility}

This refers to "the degree to which an innovation is perceived as being consistent with existing values, past experiences and needs of potential adoption" (Rogers, 1995). This means that an idea that is incompatible with the organization' snorms, values, and practices isnot adopted as quickly as those that are compatible. There are suggestions that technological innovations spread more easily and freely where such applications appear to match the adopter's processes (Ifinedo, 2011). Many studies have all confirmed the existence of positive relationship of compatibility and also as a significant predictor of various IS innovation adoption in different industries (Chaveesuk, 2010; Grublješič \& Jaklič, 2015; Lai et al., 2014; Olexová, 2014; K. Ramamurthy et al., 2008; Pearson \& Grandon, 2005; Moore \& Benbasat, 1991). However, other studies did not find support for this factor as a determinant or predictor for the adoption of IT/IS in organizations (Ifinedo, 2011; Premkumar \& Roberts, 1999; Thiesse et al., 2011). Based on these, we therefore hypothesized that:

H3: Compatibility of BI applications is positively related to BI Systems Adoption

\section{Organizational Factors}

\section{Organizational Size}

This refers to the size of the organizational resource base (in terms of number of employees and annual sales revenue) that can influence the adoption of new technological innovation (Ifinedo, 2011; Oliveira et al., 2014; Premkumar \& Roberts, 1999; Thiesse et al., 2011). Generally, larger firms are found to have more slack resources and as a result are able to experiment with and also take greater risks associated with new innovations (Oliveira et al., 2014; Premkumar \& Roberts, 1999; Puklavec \& Oliveira, 2014; K. (Ram) Ramamurthy et al., 2008). Several studies have shown that the size of an organization plays a very important/significant role and has an impact on its technological innovation adoption (Chaveesuk, 2010; Hwang, Ku, Yen \& Cheng, 2004; Malladi, 2013; Puklavec \& Oliveira, 2014; K. (Ram) Ramamurthy et al., 2008). However, other studies have also found out that size does not play a significant role when it comes to Organizational adoption of various IS in different industries (Ifinedo, 2011; Oliveira \& Martins, 2010b; Thiesse et al., 2011). Based on these, we therefore hypothesized that:

H4: Organizational Size is positively related to BI Systems Adoption

2. Top Management Support

Thong et al. (1996) defines Management support as "active engagement of top management with IS implementation". This is so, asgenerally, top managers act as the change agents in the adoption process of new technological innovations (Ifinedo, 2011; Thong et al., 1996). In firms where 
management support is low or absent, technology acceptance and adoption usually tend to be put on hold in terms of organizational priorities and eventually fail to produce satisfactory outcomes (Ifinedo, 2011). Many studies have shown that top management support encourages technology usage and gives better performance, and is one of the strongest enablers ofinnovation implementation (Bijker \& Hart, 2013; Chaveesuk, 2010; Tanja Grublješič \& Jaklič, 2015; Hwang et al., 2004; Ifinedo, 2011; Premkumar \& Roberts, 1999; Puklavec \& Oliveira, 2014; K. (Ram) Ramamurthy et al., 2008; Thiesse et al., 2011; Wixom \& Watson, 2001). However, other studies did not find executive support as a determinant of innovation adoption (Sujitparapitaya et al., 2012). Based on these, we therefore hypothesized that:

H5: Top Management Support is positively related to BI Systems Adoption

\section{Presence of Champion}

Premkumar et al. (1997) and Yeoh \& Koronios (2010) describe a champion as a highly enthusiastic person with in-depth knowledge of the business processes of the organization as well as the technological innovation being discussed and committed to the innovation. Champions actively support, and promote the project by creating awareness, provide information, political support, material resources, and play a significant role in gaining organizational acceptance of the innovation which are very important to impact successful adoption and implementation (Gu et al., 2012; Meyer, 2000; Premkumar et al., 1997; Wixom \& Watson, 2001). Therefore, organizations tend to havea higher adoption level, if they appoint a project champion who has a related background to the innovation under consideration (Chong et al., 2009; Puklavec \& Oliveira, 2014). Many studies have consistently found that the presence of a champion enabled the adoption, is a determinant and played a significant role (Gu et al., 2012; Hwang et al., 2004; C.-P. Lee \& Shim, 2007; C. Olszak \& Ziemba, 2012; Puklavec \& Oliveira, 2014; Yeoh \& Koronios, 2010). Based on these, we therefore hypothesized that:

H6: Presence of a Champion is positively related to BI Systems Adoption

\section{Organizational Readiness \\ Many studies have described Organizational}

Readiness as the financial resources, organizational IT sophistication, and the human knowledge of IS that exist in an organization(Ifinedo, 2011; Iacovou, Benbasat \& Dexter, 1995; Al-Qirim, 2008; Ramdani et al., 2009). Oliveira et al. (2014) argued that the specialized human resources are the people within the organization with the skill and knowledge to implement, and manage the innovation under consideration, and together they improve the technological readiness of an organization. Puklavec \& Oliveira (2014) explained that BI Systems exercise higher levels of voluntariness which is more sensitive for resources availability and as such slack could be an important factor of BI Systems adoption. Some previous studies in the BI Systems and other related technologies have found organizational readiness as a facilitator and determinant to BI System and other innovations adoption (Grublješič \& Jaklič, 2015; Hung et al., 2010; Lai et al., 2014; Oliveira \& Martins, 2010a; Oliveira et al., 2014; Puklavec \& Oliveira, 2014; SoaresAguiar \& Palma-dos-Reis, 2008; Wixom \& Watson, 2001; Y. Zhu et al., 2010). However, other studies did not find support for this factor (Ifinedo, 2011). Based on these, we therefore hypothesized that:

H7 Organizational Readiness is positively related to BI Systems Adoption

\section{Environmental Factors}

\section{Competitor's Pressure}

This refers to "the degree of stress that the company feels from competitors within the industry" (Oliveira \& Martins, 2010a, 2010b; Porter \& Millar, 1985). Such a competition tends to make them look for better approaches to raise their efficiency and increase productivity which leads to achieving competitive advantage (Themistocleous, Irani, Kuljis, \& Love, 2004). Sometimes, pressure from a firms external forces such as its partners, customers, and competition drives them to adopt an innovation (Ifinedo, 2011; Raymond, 2001). Also, a competitor's pressure can lead to environmental uncertainty which could increase the adoption rates of innovationsin various industries(Ifinedo, 2011; Raymond, 2001). Many empirical studies have found competitive pressure to be a determinant/predictor and significantly influence innovations adoption (Chaveesuk, 2010; Gu et al., 2012; Hwang et al., 2004; Ifinedo, 2011; H.-F. Lin \& Lin, 2008; Oliveira \& Martins, 2010a; Premkumar \& Roberts, 1999; Soares-Aguiar \& 
Palma-dos-Reis, 2008; K. Zhu \& Kraemer, 2005). However, other empirical studies did not find support for competitive pressure as a predictor for technology innovations (Oliveira et al.,2014; Thiesse et al., 2011; Pan \& Jang, 2008; Sujitparapitaya et al., 2011). Based on these, we therefore hypothesized that:

H8: Competitive Pressure is positively related to BI Systems Adoption

\section{Regulatory Body}

This refers to "the legislative regulations that the organization needs to comply with which may pose requirements or limitations to BI systems adoption" (Olbrich et al., 2012; Rosemann et al., 2006). Zhu et al. (2006) refer to regulatory support as the support given by a government authority for encouraging the absorption of IT innovation by firms. The regulatory environment isknownto be a critical environmental factor affecting innovation diffusion (Pan \& Jang, 2008). Sujitparapitaya et al. (2011) argued that many organizations are turning into BI Systems recently in order to be able to effectively respond and comply with the regulatory reporting requirements such as those set by the Exchange Commission and US Securities, as well as others mandated by the Sarbanes-Oxley Act. Oliveira et al. (2014) asserted that the influence of the existing regulations and laws can be very crucial in the adoption of new technologies, and explained further that, Government regulations can be a driver or barrier to businesses from adopting cloud computing. Prior empirical studies have found regulatory body/environment to be a predictor and significantly influencing adoption of innovations (Zhu \& Kraemer, 2005; Zhu et al., 2006). However, other studies did not find a significant influence for this factor (Oliveira et al., 2014; Pan \& Jang, 2008). Based on these, we therefore hypothesized that:

H9: Regulatory Body is positively related to BI Systems Adoption

\section{Mediating Variable}

\section{BI Systems Adoption}

Rogers (1962:17) sees adoption as "a decision to continue full-scale use of an innovation". Hence in this study, BI Systems Adoption refers to the bank's adoption, implementation and use of BI Systems based on the Rogers definition. Many prior studies based on innovation adoption theories such as DOI,
TOE, INT, TAM, TPB, UTAT and so on, have all used this variable as the dependent variable (Chaveesuk, 2010; Ghobakhloo, Arias-Aranda \& Benitez-Amado, 2011; Gu et al., 2012; Oliveira et al., 2014; Premkumar et al., 1997; Premkumar \& Roberts, 1999; K. (Ram) Ramamurthy et al., 2008; Thiesse et al., 2011; Yoon et al., 2014). However, few other studies have also used it as a mediating variable which leads to evaluating the post-adoption effects of innovations (Park \& Rim, 2011; K. Ramamurthy et al., 2008). Again, in this study, BI Systems Adoption is used as the DV for the determinants of the BI Systems adoption but as an IV for the main DV (Organizational Performance) in the model. Based on these, we therefore hypothesized that:

H10: BI Systems Adoption positively influences Organizational Performance in terms of employees' Learning and Growth.

H11: BI Systems Adoption positively influences Organizational Performance in terms of improving Internal Process.

H12: BI Systems Adoption positively influences Organizational Performance in terms of Customer Management.

H13: BI Systems Adoption positively influences Organizational Performance in terms of financial gains.

\section{Moderating Variable}

\section{Time since Adoption}

This refers to the length of time the Bank had deployed the BI system (Elbashir et al., 2008; Hou, 2012). (Elbashir et al., 2008) argued that organizations tend to develop more expertise using the system more effectively after they have used it for a longer period,which in turn generatesthe most needed business benefits. They further explained that, a lot of BI Systems benefits are likely to be derived as the system evolves over time following the advancement of BI technologies and their diffusion and innovative use by the organization. In addition (Bradford \& Florin, 2003) asserted that employees become more comfortable with the system as time elapses, which leads to greater satisfaction. In this study, Time since Adoption is used as the moderating variable and is measured by the number of years since the implementation of the BI System (Bradford \& Florin, 2003; Hou, 2012). This is used to determine whether the banks that deployed BI systems earlier 
have derived the more benefits than those who are late adopters. Based on these, we therefore hypothesized that:

H14: Time since Adoption moderates the correlation between BI Systems Adoption and Performance of Learning and Growth.

H15: Time since Adoption moderates the correlation between BI Systems Adoption and Performance of Internal Process

H16: Time since Adoption moderates the correlation between BI Systems Adoption and Performance of Customer

H17: Time since Adoption moderates the correlation between BI Systems Adoption and Performance of Finance

\section{Dependent Variable (DV)}

\section{Organizational Performance}

This refers to the benefits accrued to a Bank as a result of the post-implementation effects of their BI Systems Adoption. This is adapted from the original Balanced Scorecard with its key elements Learning and Growth, Internal Business Process, Customer, and Finance. In this study, the post-adoption benefits of BI Systems are based on these four dimensions of the Balanced Scorecard.

\section{a. Learning and Growth}

This seeks to evaluate: employees work satisfaction, employees productivity, and employees retention rate and so on attributable to BI Systems usage (Brynjolfsson \& Hitt, 1996; Elbashir et al., 2008; Fang \& Lin, 2006; Kaplan \& Norton, 1992; Park \& Rim, 2011)

\section{b. Internal Business Process}

This seeks to evaluate: timely delivery of products \& services, efficiency of inventory management, shortening of work processes \& task handling time, and reduced operational cost and so on attributable to BI Systems usage (Davenport, 2000; Elbashir et al., 2008; Fang \& Lin, 2006; Kaplan \& Norton, 1992; Mirani \& Lederer, 1998; Park \& Rim, 2011)

\section{c. Customer}

This seeks to evaluate: enhancement in customer satisfaction, company image, customer loyalty, and timely delivery of products and so on attributable to BI Systems usage (Davenport, 2000; Elbashir et al., 2008; Fang \& Lin, 2006; Kaplan \& Norton, 1992; Park \& Rim, 2011)

\section{d. Finance}

This seeks to evaluate: corporate cost reduction, increase in sales, increase in return on investment (ROI), increased revenues, and improved competitive advantage and so on attributable to BI Systems usage (Kaplan \&Norton 1992; Park \& Rim 2011; Fang \& Lin 2006; Bradford \& Roberts, 2001; Elbashir et al., 2008).

\section{RESEARCH METHOD}

As this study pertains to the development of an organizational integrated model for determining the adoption of BI Systems and also measures the postadoption benefits on banks, the deductive approach to theory through critical review of literature was adopted (Creswell, 2013; Saunders, Lewis, \& Thornhill, 2009). The next stage is the validation of the integrated model. Currently, BI Systems usage is fairly new in Ghana and it has been established that these systems exist in the banks and that's why the choice of this sectorwas made (Gyimah \& Ofori-Dwumfuo, 2013; Kester \& Preko, 2015).

\section{CONCLUSION}

In conclusion, this study seeks to develop an integrated model for determining factors influencing adoption of BI Systems in Banks from three perspectives: technological, organizational, and environmental context as well as evaluate the post-adoption effects on Business Performance of these banks. Precisely, this study proposes that Technological factors (Complexity, Relative Advantage, and Compatibility), Organizational factors (Organization's Size, Top Management Support, Presence of Champion, and Organizational Readiness), and Environmental factors (Regulatory Body and Competitive Pressure) have a significant influence on the adoption of BI Systems. Also, the study seeks to investigate the extent of the adoption as well as its impact on business performance of banks in terms of employees' Learning \& Growth, Customers' management, improved Internal Business Processes, and Financial gains dimensions using Time since Adoption as a Moderating variable. Drawing from the DOI, TOE, INT and the BSC as the underpinning theories, this study contributes to enrich the IS adoption literature by presenting an Integrated Model for BI Systems adoption factors and its effects on business performance in the context of banks in a developing country, Ghana. Our concept paper requires future work by performing an empirical investigation for validating the developed integrated model. This will be done through a survey data to determine the key factors influencing the adoption of BI 
Systems and also ascertain whether the banks are really benefiting from their BI Systems implementations. The unit of analysis is at the organizational level. The target respondents are Chief Information Officers (CIOs)/Information Technology (IT) Directors/IT Managers/Information Systems (IS) Managers, Business Analysts and so on, who have technical know-how about BI Systems and its benefits in the Banks under investigation. These executives are targeted since generally, they have extensive knowledge about the firm, as well as have access to the organizational data, and also have the ability to complete the questionnaire (Alsaad, Mohamad \& Ismail, 2014; Basu, Hartono, Lederer \& Sethi, 2002).Quantitative data analysis techniques will be applied to analyze the data. For practical contributions, the findings of the empirical study aim to be used to create awareness that will help organizations in other industries that want to adopt BI Systems because the enabling factors will be revealed and their effects on the organization's performance will also be discussed. This will help boost the adoption and implementation of BI Systems in Ghana where the subject is still fairly new. Also, the use of the Balance Scorecard measurement for business performance will give Senior Management of these banks deeper insights into the effects of the technology adoption on their organization. This will in turn help them formulate policies and procedures in the operational, tactical and strategic decisions of the banks. The limitations of this study include the consideration of only the adoption and the extent of adoption of BI Systems in the banks without a thorough investigation of the implementation success. Future studies can look at the implementation success of BI Systems in these banks. Again, a case study approach of selected banks for example one public and one private will also give deeper insights to the managers of the empirical findings.

\section{REFERENCES}

Al-Qirim, N. 2008. The adoption of E-commerce communications and applications technologies in small businesses in New Zealand. Electronic Commerce Research and Applications, 6(4): 462-473. D0I:10.1016/j.elerap.2007.02.012

Alsaad, A.K., Mohamad, R., \& Ismail, N.A. 2014. The moderating role of power exercise in b2b E-commerce adoption decision. Procedia-Social and Behavioral Sciences, 130, 515-523. D0I:10.1016/j.sbspro.2014.04.060

Aruldoss, M., Lakshmi Travis, M., \& Prasanna Venkatesan, V. 2014. A survey on recent research in business intelligence. Journal of Enterprise Information Management, 27(6): 831-866. D0I:10.1108/JEIM-06-2013-0029

Azvine, B., Cui, Z., \& Nauck, D.D. 2005. Towards real-time business intelligence. BT Technology Journal, 23(3): 214-225. DOI: $10.1007 / \mathrm{s} 10550-005-0043-0$

Baptista, J. (2009). Institutionalisation as a process of interplay between technology and its organisational context of use. Journal of Information technology, 24(4): 305-319. D0I:10.1057/jit.2009.15

Basu, V., Hartono, E., Lederer, A.L., \& Sethi, V. 2002. The impact of organizational commitment senior management involvement and team involvement on strategic information systems planning. Information \& Management, 39(6): 513-524. DOI:10.1016/S0378-7206(01)00115-X

Bharadwaj, S.S., \& Lal, P. 2012. Exploring the impact of cloud computing adoption on organizational flexibility: A client perspective. Paper presented at the International Conference in Cloud Computing Technologies Applications and Management, Dubai: UAE. DOI:10.1109/iccctam.2012.6488085

Bharati, P., \& Chaudhury, A. 2006. Diffusion of technology-enabled value innovation among manufacturing SMEs. Paper presented at the Americas Conference on Information System, San-Diego, CA.

Bijker, M., \& Hart, M. 2013. Factors influencing pervasiveness of organizational business intelligence. Paper presented at the Third International Conference on Business Intelligence and Technolog $y$. Valencia, SP.

Blumberg, R., \& Atre, S. 2003. The problem with unstructured data. Dm Review, 13, 42-49.

Boonsiritomachai, W., McGrath, M., \& Burgess, S. 2014. A research framework for the adoption of business intelligence by Small and Medium-sized enterprises. Paper presented at the 27th Annual Seaanz Conference in Small Enterprise Association of Australia and New Zealand, Sydney, Au.

Bradford, M., \& Florin, J. 2003. Examining the role of innovation diffusion factors on the implementation success of enterprise resource planning systems. International Journal of Accounting Information Systems, 4(3): 205-225. DOI:10.1016/S1467-0895(03)00026-5

Bradford, M., \& Roberts, D. 2001. Does your ERP system measure up? Strategic Finance, 83(3): 30-34. 
Brynjolfsson, E., \& Hitt, L. 1995. Information technology as a factor of production: The role of differences among firms. Economics of Innovation and New technology, 3(3-4): 183-200. DOI:10.1080/10438599500000002

Brynjolfsson, E., \& Hitt, L. 1996. Paradox lost? Firm-level evidence on the returns to information systems spending. Management science, 42(4): 541-558. D0I:10.1287/mnsc.42.4.541

Chand, D., Hachey, G., Hunton, J., Owhoso, V., \& Vasudevan, S. 2005. A balanced scorecard based framework for assessing the strategic impacts of ERP systems. Computers in Industry, 56(6): 558-572. D0I:10.1016/j.compind.2005.02.011

Chau, P.Y., \& Tam, K.Y. 1997. Factors affecting the adoption of open systems: An exploratory study. Mis Quarterly, 21(1): 1-24. DOI: $10.2307 / 249740$

Chaveesuk, S. (2010). The Determinants of the Adoption and Application of Business Intelligence: An ERP Perspective. PhD thesis, Victoria University, Melbourne, AU. URL: http://eprints.vu.edu.au/15983. Last accessed on 16 April 2016.

Chong, A.Y.L., Lin, B., Ooi, K.B., \& Raman, M. 2009. Factors affecting the adoption level of c-commerce: An empirical study. Journal of Computer Information Systems, 50(2): 13-22.

Chuah, M.H., \& Wong, K. 2011. A review of business intelligence and its maturity models. African Journal of Business Management, 5(9): 3424-2428.

Côrte-Real, N., Ruivo, P., \& Oliveira, T. 2014. The diffusion stages of business intelligence \& analytics (BI\&A): A systematic mapping study. Procedia Technology, 16, 172-179. DOI:10.1016/j.protcy.2014.10.080

Creswell, J.W. 2013. Research design: Qualitative, quantitative, and mixed methods approaches. Lincoln, US: Sage Publications.

Curko, K., \& Bach, M.P. 2007. Business intelligence and business process management in banking operations. Paper presented at the 29th International Conference on Information Technology Interfaces, Cavtat, HR. DOI: 10.1109/iti.2007.4283744

Davenport, T.H. 2000. Mission critical: Realizing the promise of enterprise systems. Boston, MA: Harvard Business School Press.

Davenport, T.H. 2006. Competing on Analytics. Harvard Business Review, 84(1): 98-107.

Dawson, L., \& Van Belle, J.P. 2013. Critical success factors for business intelligence in the South African financial services sector. SA Journal of Information Management, 15(1): 1-12. D0I:10.4102/sajim.v15i1.545

De Voe, L., \& Neal, K. 2005. When business intelligence equals business value. Business Intelligence Journal, 10(3): 57 63.

DiMaggio, P.J. \& Powell, W.W. 1983. The iron cage revisited: Institutional isomorphism and collective rationality in organizational fields. American Sociological Review, 48(2): 147-160. D0I:10.2307/2095101

Eckerson, W. (2003). Smart companies in the 21st century: The secrets of creating successful business intelligence solutions. TDWI Report Series.

Elbashir, M.Z., Collier, P.A., \& Davern, M.J. 2008. Measuring the effects of business intelligence systems: The relationship between business process and organizational performance. International Journal of Accounting Information Systems, 9(3): 135-153. DOI:10.1016/j.accinf.2008.03.001

Fang, M., \& Lin, F. 2006. Measuring the performance of ERP system-from the balanced scorecard perspectives. Journal of American Academy of Business, 10(1): 256-263.

Fedouaki, F., \& El Alami, S. 2013. A maturity model for business intelligence system project in small and sedium-sized enterprises: An empirical investigation. International Journal of Computer Science Issues, 10(6): 61-69.

Ghobakhloo, M., Arias-Aranda, D., \& Benitez-Amado, J. 2011. Adoption of e-commerce applications in SMEs. Industrial Management \& Data Systems, 111(8): 1238-1269. D0I:10.1108/02635571111170785

Gibbs, J.L., \& Kraemer, K.L. 2004. A cross-country investigation of the determinants of scope of e-commerce use: An institutional approach. Electronic markets, 14(2): 124-137. DOI:10.1080/10196780410001675077

Gibson, M., Arnott, D., Jagielska, I., \& Melbourne, A. 2004. Evaluating the intangible benefits of business intelligence: Review \& research agenda. Paper presented at the Proceedings of the 2004 IFIP International Conference on Decision Support Systems (DSS2004): Decision Support in an Uncertain and Complex World, Prato, IT.

Varun Grover, T.H.D. 2001. General perspectives on knowledge management: Fostering a research agenda. Journal of 
management information systems, 18(1): 5-21.

Grublješič, T., Coelho, P.S., \& Jaklič, J. 2014. The importance and impact of determinants influencing business intelligence systems embeddedness. Issues in Information Systems, 15(1): 106-117.

Grublješič, T., \& Jaklič, J. 2015. Business intelligence acceptance: The prominence of organizational factors. Information Systems Management, 32(4): 299-315. DOI:10.1080/10580530.2015.1080000

Gu, V.C., Cao, Q., \& Duan, W. 2012. Unified Modeling Language (UML) IT adoption-A holistic model of organizational capabilities perspective. Decision Support Systems, 54(1): 257-269.

Gyimah, E., \& Ofori-Dwumfuo, G.O. 2013. Business intelligence as an ict tool for financial crime detection in ghana. Research Journal If Information Technology, 5(3): 62-71.

Hartley, K., \& Seymour, L.F. 2011. Towards a framework for the adoption of business intelligence in public sector organisations: the case of South Africa. Paper presented at The Proceedings of the South African Institute of Computer Scientists and Information Technologists Conference on Knowledge, Cape Town, SA. DOI: $10.1145 / 2072221.2072235$

Hawking, P. (2013). Factors critical to the success of business intelligence systems. Doctoral disseratation, Victoris University, Melbrone, AU.

Hawking, P., Jovanovic, R., \& Sellitto, C. 2011. Business intelligence maturity in australia. Paper prsented at the 17th Americas Conference on Information Systems 2011 Proceedings Detroit, Michigan.

Hedman, J., \& Borell, A. 2004. Narratives in ERP systems evaluation. Journal of Enterprise Information Management, 17(4): 283-290. DOI:10.1108/17410390410548698

Hočevar, B., \& Jaklič, J. 2008. Assessing benefits of business intelligence systems-a case study. Management Journal of Contemporary Management Issues, 13(2): 87-119.

Hou, C.K. 2012. Examining the effect of user satisfaction on system usage and individual performance with business intelligence systems: An empirical study of Taiwan's electronics industry. International Journal of Information Management, 32(6): 560-573. D0I:10.1016/j.ijinfomgt.2012.03.001

Hou, C.K. 2014. User acceptance of business intelligence systems in Taiwan's electronics industry. Social Behavior and Personality: An international journal, 42(4): 583-596. D0I:10.2224/sbp.2014.42.4.583

Hou, C.K. 2015. Using the balanced scorecard in assessing the impact of BI system usage on organizational performance: An empirical study of Taiwan's semiconductor industry. Information Development, 31(5): 435-450. D0I: $10.1177 / 0266666915614074$

Hung, S.Y., Hung, W.H., Tsai, C.A., \& Jiang, S.C. 2010. Critical factors of hospital adoption on CRM system: Organizational and information system perspectives. Decision support systems, 48(4): 592-603. D0I:10.1016/j.dss.2009.11.009

Hwang, H.G., Ku, C.Y., Yen, D.C., \& Cheng, C.C. 2004. Critical factors influencing the adoption of data warehouse technology: a study of the banking industry in Taiwan. Decision Support Systems,37(1): 1-21. D0I:10.1016/S01679236(02)00191-4

Iacovou, C.L., Benbasat, I., \& Dexter, A.S. 1995. Electronic data interchange and small organizations: Adoption and impact of technology. MIS quarterly, 19(4), 465-485. DOI:10.2307/249629

Ifinedo, P. 2011. An empirical analysis of factors influencing Internet/e-business technologies adoption by SMEs in Canada. International Journal of Information Technology \& Decision Making, 10(04): 731-766. DOI:10.1142/S0219622011004543

Kannan, S., Pappathi, K., \& Karnan, M. 2012. Business intelligence : Financial decision support system research based on data warehouse. International Journal of Scientific \& Engineering Research, 3(5): 1-5.

Kaplan, R.S., \& Norton, D.P. 1992. The balanced scorecard - measures that drive performance. Harvard Business Review, $70,71-79$.

Kaplan, R.S., \& Norton, D.P. 1996. Using the balanced management system. Harvard Business Review, 75-86.

Kaplan, R.S., \& Norton, D.P. 2004. The strategy map: Guide to aligning intangible assets. Strategy \& Leadership, 32(5): 10-17. DOI:10.1108/10878570410699825

Kester, Q.A., \& Preko, M. 2015. Business intelligence adoption in developing economies: a case study of Ghana. International Journal of Computer Applications, 127(1): 5-11. D0I:10.5120/21077-3754

ISSN: 2414-309X

DOI: 10.20474/jabs-2.2.4 
Khojasteh, N., Ansari, R., \& Abadi, H.R.D. 2013. A study of the influencing technological and technical factors successful implementation of business intelligence system in internet service providers companies. International Journal of Academic Research in Accounting, Finance and Management Sciences, 3(2): 125-132.

Kim, J., Suh, E., \& Hwang, H. 2003. A model for evaluating the effectiveness of CRM using the balanced scorecard. Journal of Interactive Marketing, 17(2): 5-19. D0I:10.1002/dir.10051

Lai, H.M., Lin, I.C., \& Tseng, L.T. 2014. High-level managers' considerations for RFID adoption in hospitals: An empirical study in Taiwan. Journal of medical systems, 38(2): 1-17. D0I:10.1007/s10916-013-0003-z

Larsen, K. R., Allen, G., Vance, A., \& Eargle, D. (2015). Theories used in IS Research Wiki. URL: http://IS.TheorizeIt.org. Last accessed on 15 March 2016.

Lee, A.H., Chen, W.C., \& Chang, C.J. 2008. A fuzzy AHP and BSC approach for evaluating performance of IT department in the manufacturing industry in Taiwan. Expert Systems with Applications,34(1): 96-107. D0I: 10.1016/j.eswa.2006.08.022

Lee, C.P., \& Shim, J.P. 2007. An exploratory study of radio frequency identification (RFID) adoption in the healthcare industry. European Journal of Information Systems, 16(6): 712-724.

Lee, S., Park, S.B., \& Lim, G.G. 2013. Using balanced scorecards for the evaluation of Software-as-a-service. Information \& Management, 50(7): 553-561. DOI:10.1016/j.im.2013.07.006

Lin, H.F., \& Lin, S.M. 2008. Determinants of e-business diffusion: A test of the technology diffusion perspective. Technovation, 28(3): 135-145. D0I:10.1016/j.technovation.2007.10.003

Lin, H.Y., Hsu, P.Y., \& Ting, P.H. 2006. ERP systems success: An integration of IS success model and balanced scorecard. Journal of Research and Practice in Information Technology, 38(3): 215-228.

Lin, Z., Zhu, M., Yin, W., \& Dong, J. 2008. Banking intelligence: Application of data warehouse in bank operations. Paper presented at the IEEE International Conference on Service Operations and Logistics, and Informatics, Beijing, CN.

Popovič, A., Turk, T., \& Jaklič, J. 2010. Conceptual model of business value of business intelligence systems. Management Journal of Contemporary Management Issues, 15(1): 5-30.

Lönnqvist, A., \& Pirttimäki, V. 2006. The measurement of business intelligence. Information Systems Management, 23(1), 32-45. DOI:10.1201/1078.10580530/45769.23.1.20061201/91770.4

Malladi., S. 2013. Adoption of business intelligence \& analytics in organizations-an empirical study of antecedents.

Paper presentated at the 19th American Conference on Information Systems (AMCIS); Chicago, IU.

Mancini., E.H.J. \& Vaassen., R.P. Dameri . 2013. Accounting information systems for decision making. New York, US:

Springer.

Matei, G., \& Bank, R.C. 2010. A collaborative approach of Business Intelligence systems. Journal of Applied Collaborative Systems, 2(2): 91-101.

Meyer, M. 2000. Innovation roles: From souls of fire to devil's advocates. Journal of Business Communication, 37(4): 328-347. DOI:10.1177/002194360003700401

Meyer, J. W \& Rowan, B. 1977. Institutional organizations: Formal structure as myth and ceremony. The American Journal of Sociology, 83(2): 340-363. DOI:10.1086/226550

Michalska, J. 2005. The usage of The Balanced Scorecard for the estimation of the enterprise's effectiveness. Journal of materials processing technology, 162(163): 751-758. D0I:10.1016/j.jmatprotec.2005.02.227

Mirani, R., \& Lederer, A. L. 1998. An instrument for assessing the organizational benefits of IS projects. Decision Sciences, 29(4): 803-838. DOI:10.1111/j.1540-5915.1998.tb00878.x

Moore, G. C., \& Benbasat, I. 1991. Development of an instrument to measure the perceptions of adopting an information technology innovation. Information Systems Research, 2(3): 192-222. D0I:10.1287/isre.2.3.192

Mungree, D., Rudra, A., Morien, D. 2013. A framework for understanding the critical success factors of enterprise business intelligence implementation. Paper presented the Proceedings of the Nineteenth Americas Conference on Information Systems, Chicago, Illinois.

Negash, S. 2004. Business intelligence (BI). Communications of the Association for Information Systems, 13(2): 177195.

O'Brien, J., \& Kok, J. A. 2006. Business Intelligence and the telecommunications industry: can business intelligence lead to 
higher profits?. SA Journal of Information Management, 8(3): 1-16. D0I:10.4102/sajim.v8i3.231

Olbrich., S. Poppelbuß., J. Niehaves., B. 2012. Critical contextual success factors for business intelligence: a delphi study on their relevance, variability, and controllability. Paper presented at the 45th Hawaii International Conference, Maui, HI. DOI:10.1109/hicss.2012.187

Olexová, C. 2014. Business intelligence adoption: a case study in the retail chain. World Scientific and Engineering Academy and Soceity Transactions on Business and Economics, 11(4): 95-106.

Oliveira, T. \& Martins, M.F. 2011. Literature review of information technology adoption models at firm level. The Electronic Journal Information Systems Evaluation, 14(1): 110-121.

Oliveira, T., \& Martins, M. F. 2010. Firms patterns of e-business adoption: evidence for the European Union-27. The Electronic Journal Information Systems Evaluation, 13(1): 47-56.

Oliveira, T., \& Martins, M. F. 2010. Understanding e-business adoption across industries in European countries. Industrial Management \& Data Systems, 110(9): 1337-1354. DoI:10.1108/02635571011087428

Oliveira, T., Thomas, M., \& Espadanal, M. 2014. Assessing the determinants of cloud computing adoption: An analysis of the manufacturing and services sectors. Information \& Management, 51(5): 497-510. D0I: 10.1016/j.im.2014.03.006

Olszak, C. M. 2013. Assessment of business intelligence maturity in the selected organizations. paper presented at the Federated Conference In Computer Science and Information Systems, Kraków, PL.

Olszak, C. M., \& Ziemba, E. 2007. Approach to building and implementing business intelligence systems. Interdisciplinary Journal of Information, Knowledge, and Management, 2(7): 134-148.

Olszak, C. M., \& Ziemba, E. 2012. Critical success factors for implementing business intelligence systems in small and medium enterprises on the example of upper Silesia, Poland. Interdisciplinary Journal of Information, Knowledge, and Management, 7, 129-150.

Ong, I. L., \& Siew, P. H. 2013. An Empirical Analysis on Business Intelligence Maturity in Malaysian Organizations. International Journal of Information System and Engineering, 1(1): 1-10.

Pan, M. J., \& Jang, W. Y. 2008. Determinants of the adoption of enterprise resource planning within the technologyorganization-environment framework: Taiwan's communications industry. Journal of Computer information systems, 48(3): 94-102.

Park, Y.-J., \& Rim, M.-H. (2011). The Relationship Analysis of RFID Adoption and Organizational Performance. ICSNC 2011, The Sixth International Conference on Systems and Networks Communications, (c), 76-82.

Peansupap, V., \& Walker, D. 2005. Factors affecting ICT diffusion: a case study of three large Australian construction contractors. Engineering, Construction and Architectural Management,12(1): 21-37. D0I: 10.1108/09699980510576871

Pearson, J. M., \& Grandon, E. E. 2005. An empirical study of factors that influence e-commerce adoption/non-adoption in small and medium sized businesses. Journal of Internet commerce, 4(4): 1-21. D0I:10.1300/J179v04n04_01

Pilz, C., \& Ferraz, F. 2013. Analysis of Business Intelligence (Bi) Tools Adoption in Brazilian Companies. International Journal of Scientific Knowledge, 3(4): 1-9.

Ponelis, S. R., \& Britz, J. J. 2011. An exploratory study of business intelligence in knowledgebased South African SMEs. Paper presented at the Americas Conference on Information Systems. Detroit, Michigan.

Premkumar, G., Ramamurthy, K., \& Crum, M. 1997. Determinants of EDI adoption in the transportation industry. European Journal of Information Systems, 6(2): 107-121. D0I:10.1038/sj.ejis.3000260

Premkumar, G., \& Roberts, M. 1999. Adoption of new information technologies in rural small businesses. Omega, 27(4): 467-484. DOI:10.1016/S0305-0483(98)00071-1

Puklavec, B., Oliveira, T., \& Popovic, A. 2014. Unpacking Business Intelligence Systems Adoption Determinants: An Exploratory Study of Small and Medium Enterprises. Economic and Business Review for Central and SouthEastern Europe, 16(2): 185-190.

Rahman, N. 2013. Measuring Performance for Data Warehouses-A Balanced Scorecard Approach. International Journal of Computer and Information Technology, 4(1): 1-7.

Hribar Rajterič, I. 2010. Overview of business intelligence maturity models.Management: Journal of Contemporary Management Issues, 15(1): 47-67. 
Ramamurthy, K. R., Sen, A., \& Sinha, A. P. 2008. An empirical investigation of the key determinants of data warehouse adoption. Decision support systems, 44(4): 817-841. D0I:10.1016/j.dss.2007.10.006

Ramamurthy, K., Sen, A., \& Sinha, A. P. 2008. Data warehousing infusion and organizational effectiveness, Systems, Man and Cybernetics, Part A: Systems and Humans. IEEE Transactions, 38(4): 976-994.

Reinschmidt, J., \& Francoise, A. (2000). Business intelligence certification guide. IBM, International Technical Support Organization.

Ritacco, M., \& Carver, A. (2007). The Business Value of Business Intelligence - A Framework for Measuring the Benefits of Business Intelligence. Intelligence, 24.

Rob, P.,\& Coronel C. (2009). Database Systems: Design, Implementation, and Management. Eighth Edition, Thomson, Course Technology

Rogers, E.M. 1995. Diffusion of innovations. New York, US: Free Press.

Rosemann, M., Recker, J., Flender, C., \& Ansell, P. 2006. Understanding Context-Awareness in Business Process Design. Paper presented at the 17th Australasian Conference on Information Systems, Adelaide, Australia.

Rudin, K., \& Cressy, D. 2003. Will the Real Analytic Application Please Stand Up? Dm Review, 13(3): 30-41.

Saunders, M., Lewis, P., \& Thornhill, A. 2009. Research Methods for Business Students. Lombarda, IT: Pearson Education Limited.

Scott, R.W. 1995. Institutions and Organizations. Thousand Oaks, CA: Sage publications.

Soares-Aguiar, A., \& Palma-dos-Reis, A. 2008. Why do firms adopt e-procurement systems? Using logistic regression to empirically test a conceptual model. Engineering Management Transactions, 55(1): 120-133. D0I: 10.1109/TEM.2007.912806

Stratopoulos, T., \& Dehning, B. 2000. Does successful investment in information technology solve the productivity paradox? Information \& management, 38(2): 103-117. DOI:10.1016/S0378-7206(00)00058-6

Sujitparapitaya, S., Shirani, A., \& Roldan, M. 2012. Business Intelligence Adoption in Academic Administration: An Empirical Investigation. Issues in Information Systems, 13(2): 112-122.

Themistocleous, M., Irani, Z., Kuljis, J., \& Love, P. E. 2004. Extending the information system lifecycle through

enterprise application integration: A case study experience. Paper presented the Proceedings of the 37th Annual

Hawaii International Conference. Island, HI. DOI:10.1109/hicss.2004.1265558

Thiesse, F., Staake, T., Schmitt, P., \& Fleisch, E. 2011. The rise of the next-generation bar code: An international RFID adoption study. Supply Chain Management: An International Journal, 16(5): 328-345. DOI: 10.1108/13598541111155848

Thompson, 0. 2004. Business Intelligence Success, Lessons Learned. Process ERP Partners, LLC. URL: http://goo.gl/y4MSf1. Last access on 3 May 2016.

Thong, J. Y., Yap, C. S., \& Raman, K. S. 1996. Top management support, external expertise and information systems implementation in small businesses. Information systems research, 7(2): 248-267. D0I:10.1287/isre.7.2.248

Tornatzky, L. G. and Fleischer, M. 1990. The process of technology innovation. Massachusetts, MA: Lexington Books.

Turban, E., Sharda, R., Aronson, J. E., and King, D. 2008. Business Intelligence: A Managerial Approach. Boston: Pearson Prentice Hall.

Ubiparipović, B., \& Đurković, E. 2011. Application of business intelligence in the banking industry. Management Information System, 6(4): 23-30.

Watson, H. J. 2009. Tutorial: Business intelligence-past, present and future. Communications of the Association for Information Systems, 25(1): 487-510.

Weerakkody, V., Dwivedi, Y. K., \& Irani, Z. 2009. The diffusion and use of institutional theory: a cross-disciplinary longitudinal literature survey. Journal of Information Technology, 24(4): 354-368. D0I:10.1057/jit.2009.16

Wixom, B.H. \& Watson, H.J. 2001. An empirical investigation of the factors affecting data warehousing success. MIS Quarterly, 25(1): 17-41. DOI:10.2307/3250957

Wu, L., \& Chen, J. L. 2014. A stage-based diffusion of IT innovation and the BSC performance impact: A moderator of technology-organization-environment. Technological Forecasting and Social Change,88(3): 76-90. DOI: 10.1016/j.techfore.2014.06.015

Yeoh, W., \& Koronios, A. 2010. Critical success factors for business intelligence systems. Journal of computer 
information systems, 50(3): 23-32.

Yeoh, W., Koronios, A., \& Gao, J. 2008. Managing the implementation of business intelligence systems. International Journal of Enterprise Information Systems, 4(3): 79-94. D0I:10.4018/jeis.2008070106

Yoon, T. E., Ghosh, B., \& Jeong, B. K. 2014. User Acceptance of Business Intelligence (BI) Application: Technology, Individual Difference, Social Influence and Situational Constraints. Paper presented at the 47th Hawaii International Conference Waikoloa, HI. DOI:10.1109/hicss.2014.467

Zaman, M. 2005. Business Intelligence: Its Ins and Outs. ISM - Integrated System Models. URL: http://goo.gl/9DUuNH. Last access on 3 May 2016.

Zhu, K., \& Kraemer, K. L. 2005. Post-adoption variations in usage and value of e-business by organizations: cross-country evidence from the retail industry. Information Systems Research, 16(1): 61-84. D0I:10.1287/isre.1050.0045

Zhu, K., Kraemer, K. L., \& Xu, S. 2006. The process of innovation assimilation by firms in different countries: a technology diffusion perspective on e-business. Management Science, 52(10): 1557-1576. D0I:10.1287/mnsc.1050.0487

Zhu, Y., Li, Y., Wang, W., \& Chen, J. 2010. What leads to post-implementation success of ERP? An empirical study of the Chinese retail industry. International Journal of Information Management, 30(3): 265-276. DOI:

10.1016/j.ijinfomgt.2009.09.007

— This article does not have any appendix. - 